\title{
3
}

\section{The Context of Public Policy on the Sharing Economy}

\author{
Błażej Koczetkow and Andrzej Klimczuk
}

\section{Introduction}

It is much easier to talk about public policy - in general or in relation to some aspects of it - when it is viewed not as an abstract idea but as a phenomenon embedded in a given historical context. Therefore, it seems appropriate and necessary to present the (future) regulation of the sharing economy, not only as a set of possible practical solutions but also — in the spirit of the French school of Michel Aglietta (1979) —as an element characterising a given stage of capitalism. Looking at this issue from a broader perspective, not limited to specific solutions, also allows taking into account modern technologies as a factor that increasingly determines the shape of contemporary politics.

B. Koczetkow · A. Klimczuk $(\bowtie)$

SGH Warsaw School of Economics, Warsaw, Poland e-mail: aklimcz@sgh.waw.pl

B. Koczetkow

e-mail: bk85885@doktorant.sgh.waw.pl 
This chapter begins with a theoretical introduction in which, in addition to shedding light on the phenomenon of regulation related to the dominant capitalist model at a given time, we also outline contemporary features of 'digital governance.' This governance transforms political practice through changes in the regulatory activity of the state and, as such, deserves attention. On this basis, we take up the issue of what and why can be the subject of normalisation within the sharing economy and how the modern states can deal with the problems and challenges emerging in this context. At this point, it is impossible to ignore the concept of the so-called 'Regulation 2.0' and the Lex Informatica phenomenon, in which we will consider the 'esteem-based regulation' promoted by the sharing economy platforms.

Let us also emphasise that a legal regulation can be conceptualised in two ways: once as a regulation in narrow meaning, that is establishing norms; another time as its opposite, that is, deregulation. Let us assume that a key aspect of 'regulatory capitalism' is the relationship between rulemaking and commodification, which is understood as the transformation of purely social relations into market relations, with a measurable value (e.g., the commodification of education, social security, forms of neighbour help; see Esping-Andersen 1990). Moreover, although regulation in the sense of standardisation may bring to mind primarily the activities of the entities of the nation-state, there is no reason not to see it either in conflict or in agreement with regulatory activities at the global, national, regional, or local level undertaken and conducted by other entities, such as federations of non-governmental organisations (NGOs) or business associations. The subsequent sections of the chapter discuss three categories of issues relevant to public policy on the sharing economy (Table 3.1). 
Table 3.1 Topics relevant in public policy on the sharing economy

\begin{tabular}{|c|c|c|}
\hline $\begin{array}{l}\text { The potential of the } \\
\text { concept of digital } \\
\text { governance and new } \\
\text { regulatory approaches }\end{array}$ & $\begin{array}{l}\text { Positive and negative } \\
\text { effects of the sharing } \\
\text { economy }\end{array}$ & $\begin{array}{l}\text { Selected regulatory } \\
\text { instruments towards } \\
\text { the sharing economy }\end{array}$ \\
\hline $\begin{array}{l}\text { Relations of the digital } \\
\text { governance and } \\
\text { regulations }\end{array}$ & $\begin{array}{l}\text { Heterogeneous } \\
\text { approaches in } \\
\text { regulation of the } \\
\text { sharing economy }\end{array}$ & Soft law \\
\hline $\begin{array}{l}\text { Open texture, relational } \\
\text { regulation, and } \\
\text { regulation } 2.0\end{array}$ & $\begin{array}{l}\text { The challenge of } \\
\text { algorithmic } \\
\text { regulation }\end{array}$ & Rules and standards \\
\hline $\begin{array}{l}\text { Self-regulation in the } \\
\text { sharing economy }\end{array}$ & $\begin{array}{l}\text { Directions of } \\
\text { regulating the } \\
\text { sharing economy }\end{array}$ & $\begin{array}{l}\text { Individual normativity } \\
\text { and esteem-based } \\
\text { regulation }\end{array}$ \\
\hline
\end{tabular}

Source Own elaboration

\section{The Potential of the Concept of Digital Governance and New Regulatory Approaches}

\section{Relations of the Digital Governance and Regulations}

The current considerations about possible regulatory solutions should be placed in the broader context of digital governance or digital comanagement. It should be noted that governance-due to the suggested logic of intervention-is taking into account the network of actors going beyond the narrow understanding of 'government' (Oramus 2015). Within the concept of digital governance, public problems (e.g., changes in forms of employment and unemployment; commodification of cooperation and favours among the inhabitants of the municipality or local community; changes in ownership) are seen more through the prism of their consequences rather than their causes (the causal links that led to them). Nowadays, there is a widespread opinion that global dependencies and processes speak against ambitious intervention plans, conceived as a top-down attempt to reach the causes of problems or find solutions by means of socio-political engineering. By focusing on effects rather than cause-effect chains, the forms and practice of intervention policies are distinct from those that are at the root of the problem. 
The presented approach is considered to be a type of depoliticisation activity (Chandler 2019). Meanwhile, discussions that have so far dominated the issue of causation could not ignore socio-political analyses and ways of making political choices. In such cases, decision-making inherent in sovereign power and political responsibility came to the fore. The critical issue of causality is connected with the assumption that power operates hierarchically (and is not networked, as it is proclaimed in the governance approach) and that the results of politics are the result of well-thought-out choices, games of power, and possibilities. While controlling cause-and-effect relationships is-as Giorgio Agamben (2014) writes - the essence of politics, controlling effects is its opposite. The philosophical dimension of such a vector shift should not escape our attention: it reveals an epochal change in the very idea of governance. If it is difficult to control the causes, it is safer and more beneficial to try to control the effects. 'Consequence management' can therefore be seen as breaking ties with the modernist or causal understanding of governance.

Additionally, the shift from causality to effects is reflected in a corresponding shift in the conceptualisation of governance as such. Digital governance-understood as an attempt to improve social responses to effects-shifts the focus from the formal (legal) and public political sphere to the ability of systems or entire societies to respond to changes in their environment (Chandler 2019). Exercising power over the effects means transformations in the redistribution of agency, understood precisely as the ability to react, and thus allows governments to avoid the problem of responsibility for problems and the need to make decisions, which are an element of political decision-making. Political interventions are now taking the form of digital governance, as governments perceive the effects of indeterminism and risk as inherent in the complex and interdependent contemporary world. This kind of attitude seems to break with the current understanding of problems in line with the modernist logic of solutionism and progress.

The example of studies on German administrative law shows how the modern regulatory approach is oriented towards behavioural regulation, and the law is considered as a means to achieve goals appropriate in a given context, set taking into account organisational and procedural issues (Burgi 2020). The shift towards the results that comes from certain 
regulatory choices is largely due to the fact that the modern welfare state-with its ambition of social engineering through law-has led to the application of the law to many areas of social life (e.g., education, health protection, labour market, municipal housing). However, despite this intense activity, the law proved incapable of ensuring the implementation of these goals. The discourse around law-making, changes in the perception of the role of the state and the ineffectiveness of traditional legal tools have called into question the usefulness of the traditional approach to the current challenges of public administration and administrative law. However, whatever we are saying about the mechanics of law-making as they are prevalent at a given moment, one should bear in mind that the question of whether consumer-friendly laws really work or just deepen the incompetence of consumers is rarely asked. There is no law that could replace common sense and basic financial knowledge. Nevertheless, one possible effect of introducing consumer-friendly laws is that the consumer gains more consciousness of minimum standards that should be expected from financial providers. Another effect can be the implementation of minimum levels of protection (Kawiński 2009).

Let us add after Antoine Garapon and Jean Lassègue (2018) that in the case of digitalisation, which is central in the context of sharing economy platforms, the core is a radical project aimed at a new world order, grounded in new ways of empowering, manufacturing and authentication that builds trust. The economy and digital technology are presented as means by which social life could do without a political foundation. In this way, a new being arises homo numericus, the variation of which is homo ceconomicus. While in the classical model, it is assumed that the public authority communicates with the society by means of obligations (i.e., the law), the new type of social solidarity, shaped with the progress of modern technologies, allows the authority to express itself in digital interactions. Therefore, it cannot break away from them because it is based on the commodification of personal data ('surveillance capitalism;' see Zuboff 2019). The control of individuals is organised similarly: no longer from the outside, but from the inside; no longer vertically, but horizontally; not by orders, but by interactions; not in a 
narrower context, but on the web; and not through forms, but performatively-despite the risk that the mediation of forms is an indispensable condition of freedom.

\section{Open Texture, Relational Regulation, and Regulation 2.0}

Bronwen Morgan (2015) writes that there is a shift from hierarchy to network; from a regulatory agency to regulatory space; and from sovereignty to remote governance. All these features characterise new public governance, digital co-management, and digital governance. According to the post-structural position, the essence of this transformation is not so much the reduction of the regulatory power as its dispersion. Therefore, it refers with a distance to the claims about the prospects for individual emancipation. He also questions the thesis that regulatory solutions in the spirit of 'open texture' should relieve tensions between the market and the state. This is due, in part, to the idea that power should be more productive than punitive, and the emphasis should shift from formal state power to how indirect regulation of social activity fosters the emergence of self-disciplined entities.

Moreover, referring to the findings of Ruthanne Huising and Susan S. Silbey (2011), Morgan (2015) also points to 'relational regulation,' a characteristic of dynamic interdependence in relationships between 'sociological citizens.' This peculiarity, or sociological character, means in a regulatory context that individuals who are characterised by it go beyond their customary assigned tasks, formal roles, and professional group duties. What they undertake (either in return or in addition) is participation in alliances aimed at achieving regulatory goals. Entities become sociological actors because they develop an awareness of regulatory categories and the possibility of applying them in multiple social and political circumstances.

Relational regulation in terms of Huising and Silbey (2011) undermines the claim that it is necessary to eliminate the difference between 'the law on paper' and 'the law in action.' Rather, the focus is on the problem of how and what means a practically observed departure from 
the current model that can not only be approved as a daily practice but also acquire the attribute of legality—on the sole principle of persistence and prevalence of a given phenomenon-practice.

Moreover, another innovative approach to the contemporary understanding of regulation was presented by Abbey Stemler (2017). This scholar assumes that due to profound changes in technology, traditional regulation methods ('Regulation 1.0') are not able to satisfy the public interest. The 'Regulation 2.0' comes in handy, the essence of which includes three basic assumptions: (1) reliance on results (and not performance) standards; (2) privileging private (e.g., non-state) actors in setting standards; and (3) giving priority to audited self-regulation. Regulation 2.0 is complemented by public policy instruments encapsulated in the Lex Informatica formula, i.e., technical solutions (architecture of computer software) which define the scope of their users' activities.

\section{Self-Regulation in the Sharing Economy}

Self-regulation brings to mind the category of corporate social responsibility (CSR), although—as Renginee G. Pillay (2014) shows-its contemporary understanding is radically different from that which, several decades ago, equated the obligations of enterprises towards society (stakeholders) with those that they had with their shareholders. We pay attention to CSR here because its essential features include, among others, focus and reliance on corporate self-regulation and voluntary action as mechanisms organising specific areas of social life. The discussed concept focuses on the bottom-up norm-creating activity of private actors (e.g., enterprises), positioning itself in opposition to top-down legislation, i.e., legislation originating from the state and sanctioned by it. An expression of such activity is, for example, adopting 'binding corporate rules' as part of corporate governance. Thus, CSR supports the postulate that the state should play the smallest possible role in the economy. The arguments behind this position emphasise that unjustified state interventions in the economy may disrupt the beneficial processes of increasing efficiency and maximising profits. 
However, in the context of regulatory actions, it is worth noting that in recent years, the concept of CSR has been criticised, which has not bypassed the mechanisms of voluntary self-regulation used by corporations, expressed in individual regulatory actions. The effectiveness of corporate responsibility in which accountability and transparency are to be self-regulated rather than subject to state regulation has been denied. As Peter Newell (2002) writes, the reason for the critical position is the existence of two limitations of business responsibility: (1) which concerns its scope (object), and (2) which relates to the practice of sanctioning infringements.

Those who raise concerns about corporate responsibility fall into two groups. The first, less radical, advocates state sanctioning of 'private regulations' and non-regulatory instruments. This would reduce the risk that non-state solutions do not go beyond the declarations. The second group, going further, takes the position that under the guise of CSR based on voluntary actions and self-regulation, enterprises play a game of appearances. Its aim is, on the one hand, to convince that corporations are interested in moderating external costs (e.g., environmental pollution, destroying local cultures, 'digital disruption' of traditional sectors), and-on the other hand-to prevent proper, i.e., state-derived regulation. According to critics, even if social activity-including the activity of strong NGOs - can make a significant contribution to mitigating irregularities related to economic activity, it will never replace state regulation.

\section{Positive and Negative Effects of the Sharing Economy as a Regulatory Challenge}

\section{Heterogeneous Approaches in Regulation of the Sharing Economy}

According to Kathleen Thelen (2018), the literature on the political economy of advanced capitalism basically formulates two views on the causes of heterogeneous regulation of new phenomena. The first view, with an evident liberal character, explains this heterogeneity in such a 
way that the advent of new business models entails deregulation because the rapid pace of technological development allows some companies, such as Uber, to exploit loopholes in existing legal systems. These types of companies can use grey zones to establish robust operational structures, supported by enthusiastic consumers, and thus- through the accomplished fact method - to 'regulate' the area they have annexed before the state actors react (see Dumančić and Čeh Časni 2021). As a consequence of such action, pressure is put on the legislators to approve established practices in advance.

On the other hand, the second view sees the reasons for the various regulatory policies and refers to the existence of capitalist variations, showing the differences between the liberal market economies (e.g., United States) and coordinated market economies (concentrated in countries of continental Europe, e.g., France) (Hall and Soskice 2001). Briefly saying the liberal market economies include features such as competitive market arrangements and inter-firm relations; equilibrium achieved through the demand/supply and hierarchy; direct product competition; complete and formal contracting; freer movement of inputs; full-time employment in case of general skill and short-term employment in specific skills; wage bargain at the firm level; focus on formal education from high schools and colleges; low rate of unionisation; unequal income distribution; radical innovation; comparative advantages in high-tech and service and policies aimed at deregulation, antitrust and tax breaks. On the other hand, the coordinated market economies are characterised by the non-market relations; equilibrium achieved through the strategic interaction between firms and other actors; collaborative inter-firm ties; differentiated and niche production; incomplete legal system and informal contracting, monitoring and sanctioning institutions; shorter hours of employment in case of specific skills and long term for immobile jobs; wage bargain at the industry level; apprenticeship imparting industry-specific skills; high rate of unionisation; equal income distribution; incremental innovation; comparative advantage in manufacturing and policies focused on encouraging collaboration of firms. However, the perspective of varieties of capitalism fails to explain the lack of a homogeneous approach to regulation in case of the differences within the coordinated model. The research conducted 
by Thelen (2018) led her to conclude that the directions that individual countries such as Germany and Sweden take in the approach to the sharing economy (e.g., regarding Uber) are determined by local conditions. Of particular importance here are the balance of power and the ability to mobilise the opponents of the triumphal march of the sharing economy in given countries (e.g., traditional taxi drivers and hotel industry workers).

Using the generalisable example of the United States (with which the emergence of the sharing economy itself should be associated), let us note that the difficulty in optimally regulating the sharing economy is determined primarily by an incomplete understanding of its essence on the side of regulators and its participants (Dyal-Chand 2015). These leads, among others, to attempts to force new institutions into the old legal frameworks, which seems doomed to failure. The aforementioned confusion as to the nature of the sharing economy is problematic primarily because it shows a failure to recognise the central issue here-that the 'platform capitalism' (Srnicek 2016) has emerged as a new form of capitalism with different mechanisms for the production, distribution and redistribution of goods and services that go beyond the digital realm. As a consequence, not everything that was in line with the current model of this system is compatible with this new quality.

The sharing economy is usually associated with the activities of digital platforms, including the most popular such as Uber or Airbnb. As Vanessa Katz (2015) writes, in most cases, the activities of these platforms do not introduce new risks. After all, the same events can take place both in traditional hotels and in apartments rented via the Internet; the same events can take place in traditional taxis as in cars running under the Uber brand. At first glance, this seems to support the statement that service providers should be subject to the same obligations as traditional companies. However, in the sharing economy, the balance of power is different: service providers who use platform intermediation do not have any 'special relationship' with their service users that would justify imposing any specific obligations on them. The thesis that lawmakers hold platforms indirectly liable for the consequences of irregularities that occurred (only) in connection with their activities (e.g., 
relations under labour law, insurance law, or property law) also seems not obvious.

As far as service providers are concerned, the sharing economy obsoletes a number of assumptions that so far justified specific obligations on the part of service providers. These concerns, in particular, the weaker position of consumers and assigning service providers the role of 'least-cost avoiders,' which traditionally, due to the endangered interests of consumers, justified burdensome regulations. In addition, service providers using platforms tend to be small-scale and self-employed, which distinguishes them from organised business activities. Finally, many of the services they provide are standardised by platforms, which calls into question the thesis about a stronger market position of service providers, allowing for harmful shaping of contract terms. Taken together, this puts into question the need to regulate what they do, just as they do with companies.

On the other hand, in the case of platforms, it should first of all be noted that in many cases, they are either really the least-cost avoider (while Lex Informatica may serve to prevent unfavourable phenomena), or simply the easiest 'target' of legislators. However, most often, they function (or claim to function) as intermediaries whose role is exhausted in associating the parties to a given transaction. Therefore, their possible liability would, in principle, be indirect.

\section{The Challenge of Algorithmic Regulation}

According to Tom Slee (2017), the sharing economy is at the forefront of 'algorithmic regulation,' with computer algorithms taking the place of consumer protection laws. Proponents of such a solution believe that in a world where each service provider is assessed, the existence of legally regulated control and remedial mechanisms is losing importance because consumers themselves maintain order in the market. However, this scholar also notes that this position ignores the fact that most traditional regulations concern matters that the consumer does not see (e.g., fire protection, the way in which meals are stored and prepared, or the technical condition of cars). On the other hand, a reputation that can 
be built or lost based on consumer judgements matters in the context of the popular Silicon Valley's view that service providers on digital platforms are micro-entrepreneurs. As such, they are a variety of companies, so their reputation is a kind of brand.

Many governments have raised concerns about the sharing economy in various areas, not least with regard to consumer protection. After Thelen (2018), we may notice that there are also other questionable issues: competition and consumer protection, employment conditions, relations with social policy, and taxation of sharing economy entities. On the other hand, despite the reservations signalled, states see the sharing economy as a way to increase budget revenues and enable people to obtain additional benefits, including earnings. An expression of a more sympathetic attitude to the sharing economy will be, for example, the work that the French Senate has undertaken on the draft solutions in the field of tax law, aimed at introducing a 'simple, uniform and fair' order in the sphere of the sharing economy (SFR 2017).

\section{Directions of Regulating the Sharing Economy}

Regarding the most general approaches to regulating the sharing economy, Cristiano Codagnone et al. (2016) indicate four directions: (1) repression against illegally operating service providers; (2) regulation; (3) deregulation; and (4) tacit acceptance (tolerance) of new practices. Nevertheless, for example, Gabriel Doménech-Pascual (2016) considers a range of other possibilities. He begins with a variant, the sense of which is expressed in the assessment of how well the current standards work in the case of new phenomena. It emphasises the importance of collecting information, without which it is impossible to take deliberate action. Subsequently, this scholar analysed the idea of introducing new regulations, individual ones that were designed specifically to manage issues related to the sharing economy. Another idea presented by Doménech-Pascual is a temporary regulation, somewhat on a trial basis and also allowing the collection of new information. Later this expert also considers the concept of the coexistence of various regulatory regimes, that is, 'old' and 'new', so that-on the one hand-those 
who are threatened by the sharing economy can remain subject to the current regulation. On the other hand, there are prospects of introducing a new regulation better suited to changed circumstances. Thanks to this, there is also a kind of competition between the 'old' and 'new,' so the interested parties, on the basis of the collected information, can choose the best solutions. Finally, there are proposals for experimental legislation and the payment of compensation to those whose financial situation has suffered as a result of the expansion of the sharing economy.

Some authors, such as Diego Zuluaga (2016), questions whether the sharing economy - as such — could constitute a separate category of European regulation. Companies operating in accordance with the business models of this economic system operate in many sectors, competing both with traditional service providers and other companies. According to this scholar, there is no apparent justification for companies (platforms) to be subject to any separate regulations. In any event, new developments should not restrict the opportunities that the sharing economy presents to consumers and service providers. Especially given the fact that this economy already has an established place in many European Union (EU) countries, and it would be undesirable for EU legislation to slow down its development. Rather, regulation should further strengthen the advantages of the sharing economy rather than reduce them (e.g., flexibility, cost containment, employing those who would otherwise be unemployed). Burdensome employment regulations may contribute to reducing the number of employees and adversely affect the position of consumers. Instead, the sharing economy shows the need to liberalise existing norms. Thanks to it, companies existing on the market even before this economy began to feel competitive pressure, and regulations in the field of price regulation or consumer protection became redundant.

In the case of EU Member States, the choice between the generally outlined directions is free because-as indicated in the literature on the subject-due to the subsidiarity principle in force in the EU, solutions adopted at the local level should be the norm, and EU regulations should apply only when regulation at the regional or national level cannot meet its goals (Frenken et al. 2020). Meanwhile, many issues that may be considered requiring regulation in the sphere of the sharing 
economy are often resolved at the local level (e.g., the rules of shortterm rental apartments or transport). Under such conditions, tension may arise between the expectations formulated at the EU level regarding the sharing economy and the sector policies of a given country or region. The European Commission (EC) states in its communication that in order for Europe to fully reap the benefits of the sharing economy and stimulate the growth of European start-up platforms, there must not be 28 (before the United Kingdom's withdrawal from the EU-author's note) sets of rules related to online platforms. Divergent national or even local regulations in this regard create uncertainty for economic operators, limit the availability of digital services and cause confusion for consumers and enterprises (EC 2016). Harmonisation of regulations at the EU level, such as the adoption of the Directive on Security of Network and Information Systems (the NIS Directive) in 2016 and the General Data Protection Regulation (GDPR) in 2018, is essential to facilitate the rapid growth and intensification of innovative platforms. Finally, according to the EC, principles-based self-regulatory or co-regulatory measures, including industry tools for ensuring the application of legal requirements and appropriate monitoring mechanisms, can play a role. Underpinned by appropriate monitoring mechanisms, they can strike the right balance between predictability, flexibility, efficiency, and the need to develop future-proof solutions.

\section{Selected Regulatory Instruments Towards the Sharing Economy}

\section{Soft Law}

The division into 'soft law' and 'hard law' has attracted the interest of researchers since the 1990s. Soft law is a set of quasi-legal instruments that demonstrate the possibility of achieving regulatory policy goalsboth on a national and transnational scale-with the help of soft and even informal solutions and incentives that can be effective as when the 'hard' ones that are sanctioned by law used. Francis Snyder (1993) defines soft law as rules of solutions that, although generally not legally 
binding, have practical effects. As Anna Di Robilant (2006) writes, 'softness' is a defining feature of postmodern epistemology. The softness formula includes - on the one hand - regulatory instruments, and on the other-governance mechanisms, which in both cases, despite being referred to as a kind of normative obligation, are not based on binding provisions or the regime of formalised sanctions. The concept of soft law reflects two fundamental trends in the process of globalisation of law: the multiplication of norms and the privatisation of law. On the negative side, soft law is understood as an expression of criticism against the vertical, hierarchical, and state-oriented model of law-making. A negative definition is easier to formulate, as the term soft law from the positive side turns out to be difficult due to the multiplicity and complexity of soft law systems.

Study of Kenneth W. Abbott et al. (2000) characterised the legal norm as a composition of three elements: 'duty,' 'precision,' and 'delegation.' By 'duty' they mean an order to behave in a certain way or to refrain from acting in a certain way. By 'precision' they understand-not so much the command as its content and essence. On the other hand, by 'delegation'-authorising certain entities to lay down the content of legal norms, apply them, and settle disputes arising from them. Therefore, it is assumed that if even one of these components is missing, a given norm may still be considered legal, but it cannot be classified as hard lawit is connected with the assumption that soft law does not include all elements of hard law.

With reference to Fabien Terpan (2015), let us modify the above assumptions only to such an extent that precision will cease to be a necessary component, and instead of delegation, we will talk about 'execution.' On the one hand, to speak of an obligation, two elements are indispensable: the source and the content. The softness of duty results from soft instrumentum or soft negotium, but both may be included alternatively or cumulatively. On the other hand, duty is hard when both its source and content are hard. However, the dividing line between hard law and soft law is also determined by the way in which a given obligation is executed. The following possibilities can be distinguished here: hard execution, soft execution and no execution. The first of these options essentially covers those cases where the performance of duties is subject to judicial review 
(e.g., financial penalty for illegal competitive practices of taxi companies, prohibition of activity for short-term rentals at the local level). On the other hand, soft enforcement applies to situations in which punishing or limiting mechanisms are not applied (e.g., publication of local guidelines or education measures for capacity building). Where no execution is foreseen, in principle, there is no law, even understood as soft law. The two moments highlighted above: source and sanction-allow soft law to be defined as an autonomous normative category. Regulations are considered to be soft law when at least one of the above elements (source and sanction) is not hard.

\section{Rules and Standards}

Let us note that regardless of what model of regulation is used to regulate a given social phenomenon, rules can be divided into 'rules' and 'standards.' The rules are precise and formulated ex-ante, and their role is to indicate to the addressees whether a given behaviour will be legal or not. When it comes to rules, it is important that they are recorded as detailed as possible; otherwise, their addressees will not know how to proceed with certainty. On the other hand, the standards at the time of their establishment remain largely general (e.g., 'due diligence'). These general formulas are filled with content only when the addressee of the standard has already behaved in some way-then it is for the authority applying the law to determine whether the behaviour complied with the standard or not.

When it comes to standards, the following are distinguished: purposeful standards, result-oriented standards, and specificationoriented standards (Surdej 2014). The first type of standards set out only goals that the regulated entities should meet but do not indicate the ways in which it should be done. The result and specification standards define the conditions that must be met by a given product, service, or enterprise. However, the result-oriented standards do not specify how these conditions are to be met, and the specification-oriented standards do so in detail. 
It is sometimes said that the application of standards in regulation promotes innovation and leads to increased rationality and consistency within individual industries, types of services and organisations (Blind 2016). Setting standards gives rise to disputes between numerous actors in complicated power systems, including international corporations, organised interest groups or state regulators (e.g., in the electronic communications sector, radio and television sector, energy sector, and financial markets). Regardless of the results of these conflicts, it can generally be said that the existence of standards is often attributed to granting significant power to entities located between the policy area and the strictly economic sphere, which is an alternative solution to traditional state regulation (Graz 2019).

In the literature that deals with the choice between principles and standards, it is usually assumed that standards perform better in those cases where the normalised behaviour is less frequent than more frequent, and at the same time is heterogeneous (not all cases are homogeneous) (Korobkin 2000). Since these cases are rather rare, the costs of designing detailed standards are omitted. Principles reduce the cost of making decisions in the specific cases to which they apply, and these cases are generally frequent and homogeneous. The economy of scale is at work here: it is enough to adopt the rule once, and there is no need to check every time whether the behaviour was within the standard. So far, we may risk the hypothesis that there are no clear examples of already advanced and bottom-up standardisation initiatives in the sharing economy.

\section{Individual Normativity and Esteem-Based Regulation}

In the context of regulating the sharing economy, there is also the issue of the so-called 'individual normativity,' understood as one of the ways of regulating the considered phenomenon. Admittedly, regulation is associated with the activity of an external entity towards persons whose behaviour is subject to regulation. As Vincent Gautrais (2018) notes, in today's increasingly complex society, it is difficult to lay down general abstract standards with universal application, using general 
clauses, expressed, for example, in the slogans such as 'appropriate' or 'reasonable.' Therefore, it is necessary to consider the procedural law, the meaning of which is expressed in focusing on the bottom-up evaluation of the activities of regulated actors. The author also points to the possibility of a specific regulation through 'documentation,' which basically means creating one's own rules-those based on formal law, those based on less formal standards generally accepted by standardisation institutions or customarily followed in a given branch of the economy or community. In addition, as part of the process-oriented approach, there may also be control (auditing) instruments, the essence of which includes-depending on the model chosen: (1) actions essentially aimed at detecting irregularities or (2) enabling an overview of the entire institution or phenomenon under consideration.

The issue of regulation related to the concern for 'respect' and 'esteem' deserves a special mention in the context of assessing the participants of digital platforms. Richard H. McAdams (1997) writes that in the 1980 s, rational choice theorists drew attention to the fact that members of some social groups living in Asia (with a homogeneous ethnic structure) as a rule fulfilled their contracts, despite the lack of a particular enforcement apparatus. Under these conditions, this tendency to keep one's word was explained thanks to the social ties that gave members of these groups the possibility of informally punishing violations. Using considerations about the individual costs of execution that discourage individuals from engaging in sanctioning norms, Richard H. McAdams advances the importance of respect as the soil from which norms grow. Thus, people have the opportunity to punish violators at no cost, and the punishment is to refuse to show respect to someone who wants to enjoy it. According to the cited scholar, it is the desire for respect-when it manifests itself under appropriate conditions - that creates the norm.

Therefore, let us discuss the conditions for the formation of a norm. There must be an agreement among a certain group of people as to how, right, or wrong, a given behaviour is assessed. Then there is a risk of detecting abnormal behaviour. Finally, both the agreement itself and the risk of breaches being detected must be widely known in a given environment. Where respect is desired, and all the above-mentioned conditions have been met, the violator must take into account the cost 
of violating the norm, and the standard itself arises when, for a sufficient number of people in a given population, the (image) cost of such violation exceeds the cost of complying with the norm. According to Richard H. McAdams (1997), what limits the scale of normalisation is the expected high cost of their enforcement. However, where anyone can get either reward someone for following the rules or punish them for breaking them, there is no incentive to break the rules. Nevertheless, it cannot be assumed that respecting or denying respect is norm-setting in itself. Whether this will happen depends, among others, on the importance attached to the estimate, the power of understanding between the interested parties, and whether the knowledge of these matters has been sufficiently disseminated, and the cost of compliance with the standards itself.

\section{Summary}

It will not be an exaggeration to suppose that as the sharing economy develops, the law will undergo fundamental changes. It is not just that radical technological progress leaves law far behind socio-economic challenges. Furthermore, it seems equally important that the development of the sharing economy heralds a change in the perspective from which not only the law itself is perceived but also the state as the organiser of social life. It ceases to be invariably linked to the hierarchy associated with the traditional law-making activity of the state. In more and more digital times, hierarchical structures are beginning to give way to self-organising networks, and in their case, the impact of law-making is not obvious.

Therefore, it seems desirable that, instead of trying to force the sharing economy into the framework of traditional law (which-apart from the purposefulness and effectiveness of such activities-is possible), we should consider keeping pace with the rather irreversible changes. As a result, however, there is a fear of moving from one extreme to the otherfrom a conservative approach in which it is appropriate to seek to harness novelty with well-known tools or to take no action, to a revolutionary zeal for change in which it is easy to overlook the threats to citizens states.

The search for intermediate solutions-perhaps imperfect but amenable to revision-should protect those responsible for specific 
public policies from the risk of facing an accomplished fact. This task will be all the more difficult as the sharing economy is not homogeneous, and the perception of digital platforms through the prism of commonly known (e.g., Airbnb and Uber)—although understandable_obscures the picture and threatens the selection of inappropriate resources to the challenges.

It is worth pointing to a number of further directions of research. First of all, it is crucial to analyse the possibility of using various instruments regulating entities and practices of the sharing economy in individual sectors. It is evident that solutions specific to some areas may not be applicable to others (e.g., regulations on sharing in the area of hospitality and mobility and the exchange of goods and services in neighbourhood groups). Secondly, it makes sense to build a set of good practices to regulate the sharing economy at various levels (local, regional and national). Thirdly, it is legitimate to try to interpret the regulation of the sharing economy through the prism of assumptions of various theories of public policy (e.g., group theories, class analysis, and analysis of transaction costs).

\section{References}

Abbott, Kenneth W., Robert O. Keohane, Andrew Moravcsik, Anne-Marie Slaughter, and Duncan Snidal. 2000. 'The Concept of Legalization.' International Organization 54 (3): 401-419. https://doi.org/10.1162/002081800 551271.

Agamben, Giorgio. 2014. 'For a Theory of Destituent Power.' Chronos. Accessed September 20, 2020. http://www.chronosmag.eu/index.php/g-aga mben-for-a-theory-of-destituent-power.html.

Aglietta, Michel. 1979. A Theory of Capitalist Regulation: The US Experience. London: NLB.

Blind, Knut. 2016. 'The Impact of Standardisation and Standards on Innovation.' In Handbook of Innovation Policy Impact, edited by Jakob Edler, Paul Cunningham, Abdullah Gök, and Philip Shapira, 423-449. Cheltenham, UK, Northampton, MA: Edward Elgar Publishing. https://doi.org/10.4337/ 9781784711856.00021. 
Burgi, Martin. 2020. 'Public Administration and Law.' In European Perspectives for Public Administration: The Way Forward, edited by Geert Bouckaert and Werner Jann, 147-161. Leuven: Leuven University Press. https://doi.org/ 10.2307/j.ctvv417th.12.

Chandler, David. 2019. 'Digital Governance in the Anthropocene: The Rise of the Correlational Machine.' In Digital Objects, Digital Subjects: Interdisciplinary Perspectives on Capitalism, Labour and Politics in the Age of Big Data, edited by David Chandler and Christian Fuchs, 23-42. London, UK: University of Westminster Press. https://doi.org/10.25969/mediarep/11926.

Codagnone, Cristiano, Federico Biagi, and Fabienne Abadie. 2016. The Passions and the Interests: Unpacking the 'Sharing Economy.' Luxembourg: Publications Office of the European Union.

Di Robilant, Anna. 2006. 'Genealogies of Soft Law.' The American Journal of Comparative Law 54 (3): 499-554. https://doi.org/10.1093/ajcl/54.3.499.

Doménech-Pascual, Gabriel. 2016. 'Sharing Economy and Regulatory Strategies Towards Legal Change.' European Journal of Risk Regulation 7 (4): 717-727. https://doi.org/10.1017/S1867299X0001014X.

Dumančić, Kosjenka, and Anita Čeh Časni. 2021. 'The State of the Sharing Economy in Croatia: Legal Framework and Impact on Various Economic Sectors.' In The Collaborative Economy in Action: European Perspectives, edited by Andrzej Klimczuk, Vida Česnuitytè, and Gabriela Avram, 90-99. Limerick, Ireland: University of Limerick.

Dyal-Chand, Rashmi. 2015. 'Regulating Sharing: The Sharing Economy as an Alternative Capitalist System.' Tulane Law Review 90 (2): 241-309.

EC (European Commission). 2016. Communication from the Commission to the European Parliament, the Council, the European Economic and Social Committee and the Committee of the Regions: Online Platforms and the Digital Single Market Opportunities and Challenges for Europe. Swd(2016) 172 Final. Brussels: European Commission.

Esping-Andersen, Gøsta. 1990. The Three Worlds of Welfare Capitalism. Princeton, NJ: Princeton University Press.

Frenken, Koen, Arnoud van Waes, Peter Pelzer, Magda Smink, and Rinie van Est. 2020. 'Safeguarding Public Interests in the Platform Economy.' Policy \& Internet 12 (3): 400-425. https://doi.org/10.1002/poi3.217.

Garapon, Antoine, and Jean Lassègue. 2018. Justice digitale: révolution graphique et rupture anthropologique. Paris: Presses Universitaires de France/Humensis. 
Gautrais, Vincent. 2018. 'The Normative Ecology of Disruptive Technology.' In Law and the 'Sharing Economy': Regulating Online Market Platforms, edited by Derek McKee, Finn Makela, and Teresa Scassa, 115-147. Ottawa: University of Ottawa Press. https://doi.org/10.2307/j.ctv5vdczv.8.

Graz, Jean-Christophe. 2019. The Power of Standards: Hybrid Authority and the Globalisation of Services. Cambridge: Cambridge University Press. https:// doi.org/10.1017/9781108759038.

Hall, Peter A., and David Soskice, eds. 2001. Varieties of Capitalism: The Institutional Foundations of Comparative Advantage. Oxford: Oxford University Press.

Huising, Ruthanne, and Susan S. Silbey. 2011. 'Governing the Gap: Forging Safe Science Through Relational Regulation.' Regulation \& Governance 5 (1): 14-42. https://doi.org/10.1111/j.1748-5991.2010.01100.x.

Katz, Vanessa. 2015. 'Regulating the Sharing Economy.' Berkeley Technology Law Journal 30 (4): 1067-1126. https://doi.org/10.15779/Z38HG45.

Kawiński, Marcin. 2009. 'Consumer Protection and Dispute Resolution within the EU Financial Sector.' PROGRES 49 (6): 1-6.

Korobkin, Russell B. 2000. 'Behavioral Analysis and Legal Form: Rules vs. Standards Revisited.' Oregon Law Review 79 (1): 23-60.

McAdams, Richard H. 1997. 'The Origin, Development, and Regulation of Norms.' Michigan Law Review 96 (2): 338. https://doi.org/10.2307/129 0070 .

Morgan, Bronwen. 2015. 'Upside Down and Inside Out: Regulators and Regulatory Processes in Contemporary Perspective.' In The Handbook of Law and Society, edited by Austin Sarat and Patricia. Ewick, 150-167. Chichester: Wiley Blackwell. https://doi.org/10.1002/9781118701430.ch10.

Newell, Peter. 2002. 'From Responsibility to Citizenship? Corporate Accountability for Development.' IDS Bulletin 33 (2): 1-12. https://doi.org/10. 1111/j.1759-5436.2002.tb00025.x.

Oramus, Marek. 2015. 'Model współzarządzania (governance) i problemy dotyczące jego wdrażania w administracji publicznej.' Rocznik Administracji Publicznej (1): 179-195.

Pillay, Renginee G. 2014. 'The Limits to Self-Regulation and Voluntarism: From Corporate Social Responsibility to Corporate Accountability.' Amicus Curiae 99: 10-13.

SFR (Senate of the French Republic). 2017. Rapport D'information Fait Au Nom De La Commission Des Finances (1) Relatif À L'adaptation De La Fiscalité À L'économie Collaborative, No. 481. Paris: Senate of the French Republic. 
Slee, Tom. 2017. What's Yours Is Mine: Against the Sharing Economy. Brunswick, Vic. Scribe Publications. https://doi.org/10.2307/j.ctt1bkm65n.

Snyder, Francis. 1993. 'The Effectiveness of European Community Law: Institutions, Processes, Tools and Techniques.' The Modern Law Review 56 (1): 19-54. https://doi.org/10.1111/j.1468-2230.1993.tb02852.x.

Srnicek, Nick. 2016. Platform Capitalism. Oxford: Polity Press.

Stemler, Abbey. 2017. 'Regulation 2.0: The Marriage of New Governance and Lex Informatica.' Vanderbilt Journal of Entertainment \& Technology Law 19 (1): 87-131. https://doi.org/10.2139/ssrn.2746229.

Surdej, Aleksander. 2014. 'Regulacyjne instrumenty w polityce publicznej.' Studia z Polityki Publicznej 1 (4): 69-85. https://doi.org/10.33119/KSzPP. 2014.4.4.

Terpan, Fabien. 2015. 'Soft Law in the European Union-the Changing Nature of EU Law.' European Law Journal 21 (1): 68-96. https://doi.org/10.1111/ eulj.12090.

Thelen, Kathleen. 2018. 'Regulating Uber: The Politics of the Platform Economy in Europe and the United States.' Perspectives on Politics 16 (4): 938-53. https://doi.org/10.1017/S1537592718001081.

Zuboff, Shoshana. 2019. The Age of Surveillance Capitalism: The Fight for Human Future at the New Frontier of Power. New York, NY: PublicAffairs.

Zuluaga, Diego. 2016. Regulatory Approaches to the Sharing Economy: A Briefing. London, UK: Institute of Economic Affairs. Accessed September 20, 2020. https://iea.org.uk/wp-content/uploads/2016/07/Regulating\%20the\% 20sharing\%20economy\%20Briefing\%202016.pdf.

\section{Suggested Readings}

Corrales Compagnucci, Marcelo, Nikolaus Forgó, Toshiyuki Kono, Shinto Teramoto, and Erik P. M. Vermeulen, eds. 2020. Legal Tech and the New Sharing Economy. Singapore: Springer Singapore. https://doi.org/10.1007/ 978-981-15-1350-3.

Daugareilh, Isabelle, Christophe Degryse, and Philippe Pochet. 2019. The Platform Economy and Social Law: Key Issues in Comparative Perspective. Brussels: European Trade Union Institute.

Davidson, Nestor M., John Infranca, and Michèle Finck, eds. 2018. The Cambridge Handbook of the Law of the Sharing Economy. New York, NY: Cambridge University Press. https://doi.org/10.1017/9781108255882. 
Inglese, Marco. 2019. Regulating the Collaborative Economy in the European Union Digital Single Market. Cham: Springer International Publishing. https://doi.org/10.1007/978-3-030-30040-1.

Orsi, Janelle. 2014. Practicing Law in the Sharing Economy: Helping People Build Cooperatives, Social Enterprise, and Local Sustainable Economies. Lanham: American Bar Association.

Sundararajan, Arun. 2017. The Collaborative Economy: Socioeconomic, Regulatory and Labor Issues. Brussels: European Parliament.

\section{Relevant Websites}

Davidson, Nestor M., and John J. Infranca. 2021. 'Regulatory Challenges in the Sharing Economy.' Accessed September 20, 2020. https://www.americ anbar.org/groups/government_public/publications/public_lawyer_articles/ regulatory-challenges-in-the-sharing-economy/.

Erickson, Kristofer, and Inge Sørensen. 2016. 'Regulating the Sharing Economy.' Internet Policy Review 5 (2). Accessed September 20, 2020. https://policyreview.info/articles/analysis/regulating-sharing-economy.

Open Access This chapter is licensed under the terms of the Creative Commons Attribution 4.0 International License (http://creativecommons.org/ licenses/by/4.0/), which permits use, sharing, adaptation, distribution and reproduction in any medium or format, as long as you give appropriate credit to the original author(s) and the source, provide a link to the Creative Commons license and indicate if changes were made.

The images or other third party material in this chapter are included in the chapter's Creative Commons license, unless indicated otherwise in a credit line to the material. If material is not included in the chapter's Creative Commons license and your intended use is not permitted by statutory regulation or exceeds the permitted use, you will need to obtain permission directly from the copyright holder. 